\title{
RESPONSE OF HOT ROLLED AI-Zn-Mg-Cu-(Sc-Zr) ALLOYS TO ANNEALING WITH CONSTANT HEATING RATE
}

\author{
${ }^{1}$ Veronika KODETOVÁ, ${ }^{1}$ Martin VLACH, ${ }^{1}$ Hana KUDRNOVÁ, ${ }^{1}$ Michal LEIBNER, ${ }^{2}$ Jaroslav MÁLEK, \\ ${ }^{1}$ Petr HARCUBA, ${ }^{1}$ Vladimír ŠímA \\ ${ }^{1}$ Faculty of Mathematics and Physics, Charles University, Prague, Czech Republic, EU, \\ veronika.kodetova@seznam.cz
}

${ }^{2}$ Faculty of Mechanical Engineering, Czech Technical University in Prague, Czech Republic, EU

https://doi.org/10.37904/metal.2019.917

\begin{abstract}
In the present work hot rolled $\mathrm{AlZnMgCu}$ alloys with and without $\mathrm{Sc}, \mathrm{Zr}$ addition were studied. First, the temperature and time of annealing of hot rolling was looking for. Then, precipitation reactions of hot rolled alloys were studied by differential scanning calorimetry and microhardness measurements during annealing from room temperature up to $450{ }^{\circ} \mathrm{C}$. These measurements were compared to microstructure development that was observed by scanning electron microscope and by electron backscattered diffraction. The grain size was $\sim 20 \mu \mathrm{m}$ in the AlZnMgCuScZr and $\sim 1000 \mu \mathrm{m}$ in the AlZnMgCu alloy. Microstructure observation proved eutectic phase at (sub)grain boundaries. Primary multilayer $\mathrm{Al}_{3}(\mathrm{Sc}, \mathrm{Zr})$ particles also precipitated during casting and subsequent cooling in the alloy with $\mathrm{Sc}, \mathrm{Zr}$ addition. These particles were observed in the alloy with $\mathrm{Sc}, \mathrm{Zr}$ addition after annealing up to $450^{\circ} \mathrm{C}$, too. In the DSC curves the exothermic process at $\sim 200^{\circ} \mathrm{C}$ was observed. Activation energy of the process was calculated. There were observed constant values of microhardness (in accuracy of measurements) during annealing up to $450{ }^{\circ} \mathrm{C}$. Higher microhardness values were measured in the alloy with Sc,Zr addition.
\end{abstract}

Keywords: Al-based alloys, hot rolling, differential scanning calorimetry, SEM, primary $\mathrm{Al}_{3}(\mathrm{Sc}, \mathrm{Zr})$

\section{INTRODUCTION}

Commercial Al-Zn-Mg-Cu based alloys (7xxx series) are widely used in aircraft and automotive manufacture to produce lightweight vehicles [1-3]. Important properties that must be considered for these applications are strength, ductility, or corrosion and damage tolerance [4]. Most of these properties can be controlled through appropriate alloying, processing, or a combination of both. The precipitation sequence of $\mathrm{Al}-\mathrm{Zn}$-Mg-Cu based alloys could be described as: a) supersaturated solid solution (SSS) $\rightarrow$ GP zones $\rightarrow$ metastable $\eta^{\prime} \rightarrow$ stable $\eta\left(\mathrm{MgZn}_{2}\right)$; b) SSS $\rightarrow$ GP zones $\rightarrow T^{\prime}$ phase $\rightarrow T$ phase $\left(\mathrm{Al}_{2} \mathrm{Zn}_{3} \mathrm{Mg}_{3}\right)$ [5-7]. GP zones are generally formed during room temperature (RT) ageing or the early stages of artificial ageing. It is accepted that there are two types of GP zones, i.e., GPI and GPII [8]. Generally, GPI and GPII zones can serve as nucleation sites for the metastable $\eta^{\prime}$ phase [8]. Metastable $\eta^{\prime}$ phase, instead of stable $\eta$ phase $\left(\mathrm{MgZn}_{2}\right)$, is believed to be responsible for the peak hardening of Al-Zn-Mg-Cu alloys [8]. Precipitation sequence mainly depends on ratio of $\mathrm{Zn}$ and Mg addition [6,9].

Generally, the addition of Sc and/or Zr to the material can effectively improve strength, refine grains and inhibit recrystallization. Recent work has shown that ternary complex $\mathrm{Al}_{3}(\mathrm{Sc}, \mathrm{Zr})$ precipitates produced by additions of $\mathrm{Sc}$ and $\mathrm{Zr}$ are more stable, and promoting effect in inhibiting recrystallization is more remarkable [1,10]. For the cast ingots, the particles of primary $\mathrm{Al}_{3}(\mathrm{Sc}, \mathrm{Zr})$ phase occurs [11-14]. Primary $\mathrm{Al}_{3}(\mathrm{Sc}, \mathrm{Zr})$ particles have been investigated in a numerous studies and most of them observed the square or triangle morphological features of primary particles [11-14]. Primary particles were identified as some eutectic structure consisting of a multilayer of $\mathrm{Al}_{3} \mathrm{Sc}+\alpha-\mathrm{Al}+\mathrm{Al}_{3} \mathrm{Sc}+\ldots$ with a cellural-dendritic mode of growth or consists of $\mathrm{Al}{ }_{3} \mathrm{Sc}+\alpha-\mathrm{Al}+$ $\mathrm{Al}_{3} \mathrm{Zr}+\alpha-\mathrm{Al}+\mathrm{Al}_{3} \mathrm{Sc}+\alpha-\mathrm{Al}+\mathrm{Al}_{3} \mathrm{Zr}+\ldots$ layer $[13,14]$. 


\section{MATERIALS AND METHODS}

Two Al-6.6 wt\% Zn-3.0 wt\% Mg-1.9 wt\% Cu-0.2 wt\% Fe (AlZnMgCu) and Al-6.2 wt\% Zn-2.9 wt\% Mg-1.8 wt\% Cu-0.2 wt \% Fe-0.23 wt\% Sc-0.19 wt\% Zr (AlZnMgCuScZr) alloys were studied. The mould cast (MC) samples were annealed at temperature $300{ }^{\circ} \mathrm{C}$ for 30,60 or $120 \mathrm{~min}$ and at temperature $350{ }^{\circ} \mathrm{C}$ for 30,60 or $120 \mathrm{~min}$ and then hot rolled. Hot rolling was finished by quenching into water at room temperature (RT).

Alloys studied were isochronally annealed (in steps of $30 \mathrm{~K} / 30 \mathrm{~min}$ ) up to $450{ }^{\circ} \mathrm{C}$. The influence of the annealing on mechanical properties was studied using the Vickers microhardness (HV0.5) measured at RT. Between the measurements the samples were kept in liquid nitrogen to preserve the microstructure developed during the annealing. The thermal behaviour of the alloys was studied using differential scanning calorimetry (DSC) performed at heating rates of $1,2,5,10$ and $20 \mathrm{~K} / \mathrm{min}$ up to $450{ }^{\circ} \mathrm{C}$ in the Netzsch DSC 204 F1 Phoenix apparatus. A specimen of mass between $10-20 \mathrm{mg}$ was placed in $\mathrm{Al}_{2} \mathrm{O}_{3}$ crucibles in a dynamic nitrogen atmosphere $(40 \mathrm{ml} / \mathrm{min})$.

Electron backscatter diffraction (EBSD) was carried out to determine the recrystallization of the alloy using a JEOL JSM 7600F scanning electron microscope at $20 \mathrm{kV}$ equipped with a Nordly EBSD detector. The samples were polished in an "ELYANA 230" electrolytic polisher by using a 5 vol\% $\mathrm{HClO}_{4}$ and 1.5 vol. $\% \mathrm{HNO}_{3}$ solution in $\mathrm{C}_{2} \mathrm{H}_{5} \mathrm{OH}$. The results were processed by $\mathrm{HKL}$ Channel 5 software equipment. Microstructure development was observed by scanning electron microscopy (SEM). SEM observations were carried out in JOEL JEM 2000FX, FEI Quanta 200FEG and MIRA I Schottky FE-SEMH microscopes to determine the microstructure of the alloys, respectively. The analysis of precipitated phases was complemented by energy-dispersive spectroscopy (EDS) performed by X-ray BRUKER microanalyser.

\section{RESULTS AND DISCUSSION}

The mould cast AlZnMgCuScZr alloys were isothermally annealed at $300{ }^{\circ} \mathrm{C}$ for 30,60 and 120 min and at $350{ }^{\circ} \mathrm{C}$ for 30,60 and $120 \mathrm{~min}$. After that, samples were hot rolled with reduction $10 \%$. Hot rolling was finished by quenching into water at RT. Temperature of isothermal annealing was chosen on the base of previous research of the alloys with $\mathrm{Sc}, \mathrm{Zr}$ addition $[15,16]$. In the initial state of the $\mathrm{AlZnMgCu}(\mathrm{ScZr})$ alloys annealed at $300{ }^{\circ} \mathrm{C} / 60 \mathrm{~min}$ and subsequently annealed at $460^{\circ} \mathrm{C} / 45 \mathrm{~min}$ Sc-rich regions and particles of Al-Zn-Mg system were observed [15]. As with AlZnMg(ScZr) alloys we assume precipitation of particles of Al-Zn-Mg-Cu system after isochronal annealing at $300^{\circ} \mathrm{C} / 30 \mathrm{~min}$ and/or $350^{\circ} \mathrm{C} / 30 \mathrm{~min}$ in the $\mathrm{AlZnMgCu}(\mathrm{ScZr})$ alloys.

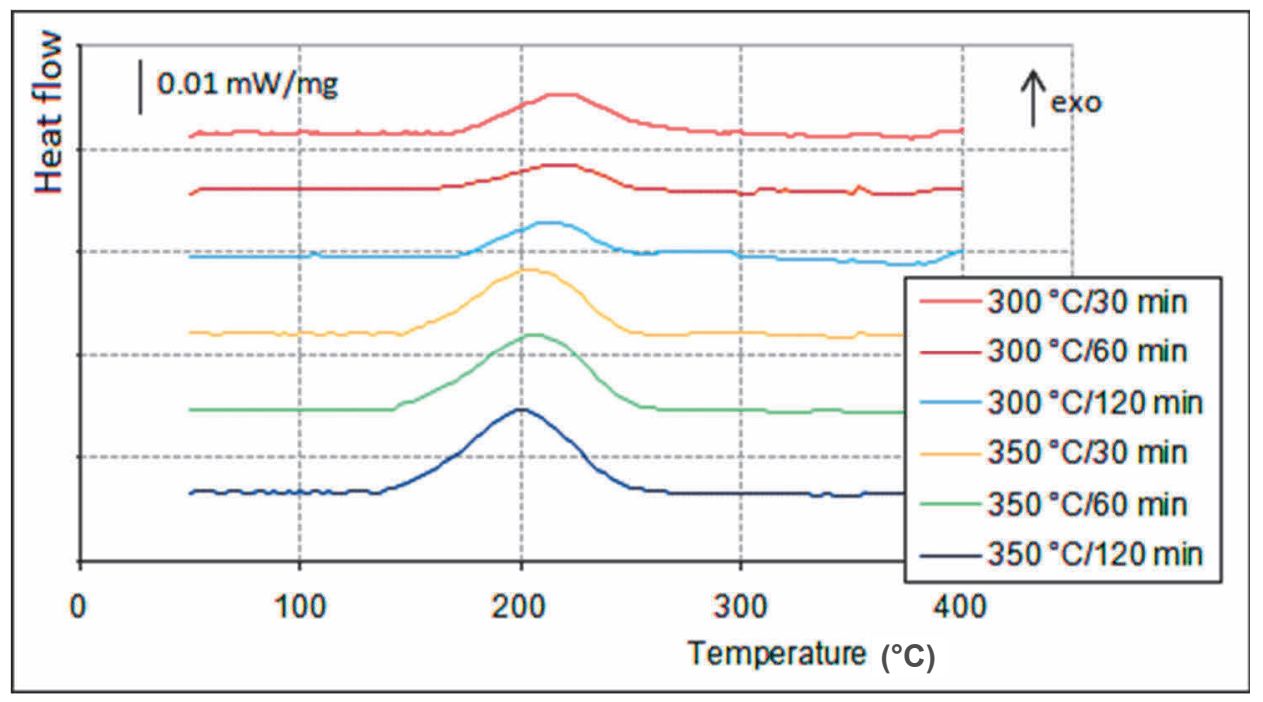

Figure $1 \mathrm{DSC}$ curves of AIZnMgCuScZr alloy isothermally annealed at $300^{\circ} \mathrm{C}$ and $350^{\circ} \mathrm{C}$ at heating rate of $5 \mathrm{~K} / \mathrm{min}$ 
All hot rolled samples were measured by differential scanning calorimetry at heating rate $5 \mathrm{~K} / \mathrm{min}$ from RT up to $400{ }^{\circ} \mathrm{C}$ (see Figure 1). DSC curves of hot rolled materials were compared to each other. In the DSC curves of $\mathrm{HR}$ alloys was observed only one exothermic process with maximum at $205{ }^{\circ} \mathrm{C}-220{ }^{\circ} \mathrm{C}$. On the base of DSC results, procedure of annealing at $300{ }^{\circ} \mathrm{C}$ for $60 \mathrm{~min}$ and then hot rolling with reduction $10 \%$ finished by quenching into water at RT was chosen for detailed analysis. This procedure of preparation will be here labelled as HR10.

The grain size of the AlZnMgCu(ScZr) alloys in the initial state was determined by EBSD measurements. The average grain size of the AlZnMgCu mould cast alloy was $\sim 1000 \mu \mathrm{m}$ and $\sim 20 \mu \mathrm{m}$ in the AlZnMgCuScZr alloy - see Figure 2 [17]. It was found that Sc,Zr addition hugely refine grains. SEM and EBSD observation showed that hot rolling of the alloys has no influence on the average grain size in both studied alloys.
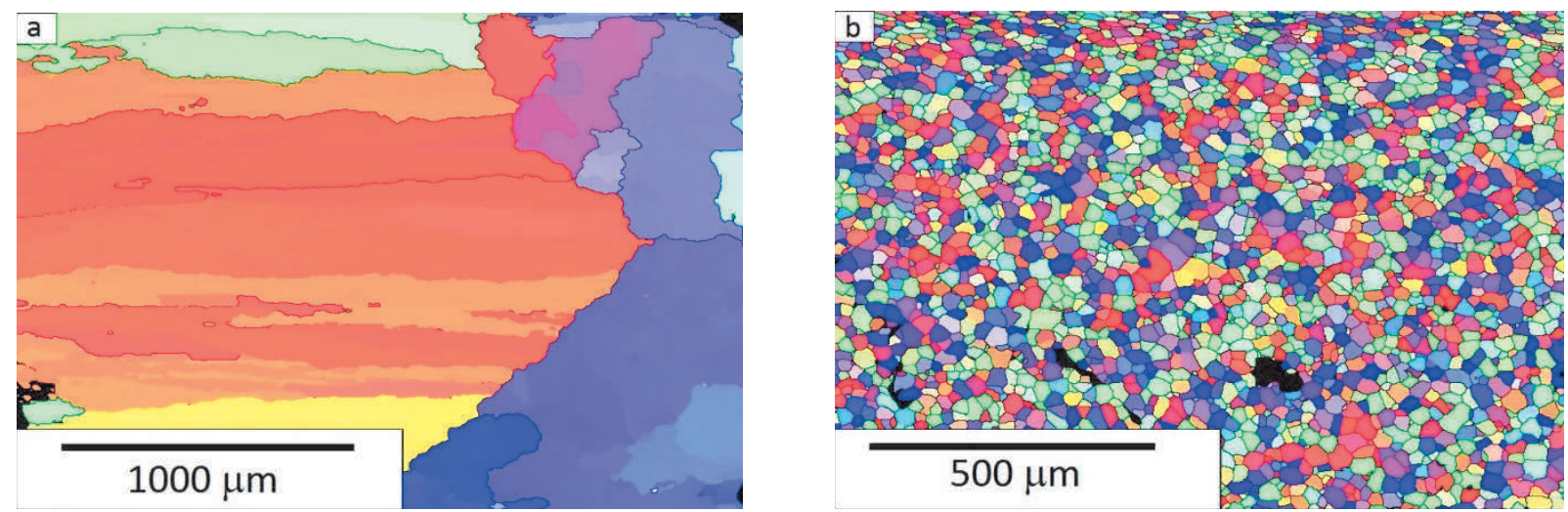

Figure 2 EBSD image of the a) AlZnMgCu, b) AlZnMgCuScZr mould cast alloys

Microstructure observations proved the eutectic phase at grain boundaries in the MC and HR10 AlZnMgCuScZr alloys and the eutectic phase at subgrain boundaries in the MC and HR10 AIZnMgCu alloys. The volume fraction of this phase was very close for both studied alloys. Primary $\mathrm{Al}_{3}(\mathrm{Sc}, \mathrm{Zr})$ particles also precipitated inside grains/on the grain boundaries in the MC and HR10 AIZnMgCuScZr alloy. The average size of these particles was observed as $\sim 2 \mu \mathrm{m}$. There were observed primary rectangular and/or triangular $\mathrm{Al}_{3}(\mathrm{Sc}, \mathrm{Zr})$ particles consists of layers both in Sc and $\mathrm{Zr}$ in the alloy by SEM and EDS. In contrast to Refs. $[13,14]$ it can be concluded that shell-like layers of primary $\mathrm{Al}_{3}(\mathrm{ScZr})$ particles in the MC and HR10 AlZnMgCuScZr alloys can be probably identified as: $\mathrm{Al}_{3}(\mathrm{Sc}, \mathrm{Zr})+\alpha-\mathrm{Al}+\mathrm{Al}_{3}(\mathrm{Sc}, \mathrm{Zr})+\alpha-\mathrm{Al}+\ldots$.
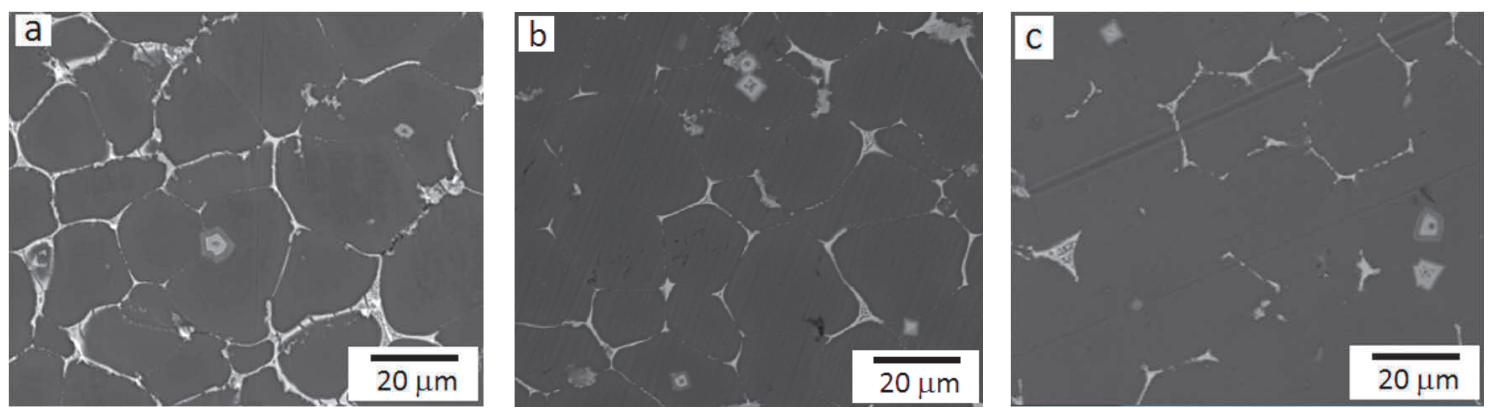

Figure 3 SEM images of AIZnMgCuScZr HR10 a) in the initial state, b) after isochronal annealing up to $210^{\circ} \mathrm{C}, \mathrm{c}$ ) after isochronal annealing up to $450{ }^{\circ} \mathrm{C}$

The evolution of primary particles was observed in the AlZnMgCuScZr HR10 by SEM during the isochronal annealing. AlZnMgCuScZr samples were prepared in four different states: HR10 in the initial state, HR10 after isochronal annealing up to $210^{\circ} \mathrm{C}, \mathrm{HR} 10$ after isochronal annealing up to $360{ }^{\circ} \mathrm{C}$ and $\mathrm{HR} 10$ after isochronal 
annealing up to $450{ }^{\circ} \mathrm{C}$. It was found that the isochronal annealing has no apparent influence neither on amount, size and shape of particles nor on composition of layers of primary $\mathrm{Al}_{3}(\mathrm{Sc}, \mathrm{Zr})$ particles. The SEM images of the HR10 AlZnMgCuScZr alloys are shown in Figure 3. One can see primary particles of the HR10 alloy, after isochronal annealing up to $210^{\circ} \mathrm{C}$ and $450{ }^{\circ} \mathrm{C}$. It can be seen that the eutectic phase at (sub)grain boundary partly dissolved after isochronal annealing up to $450{ }^{\circ} \mathrm{C}$.

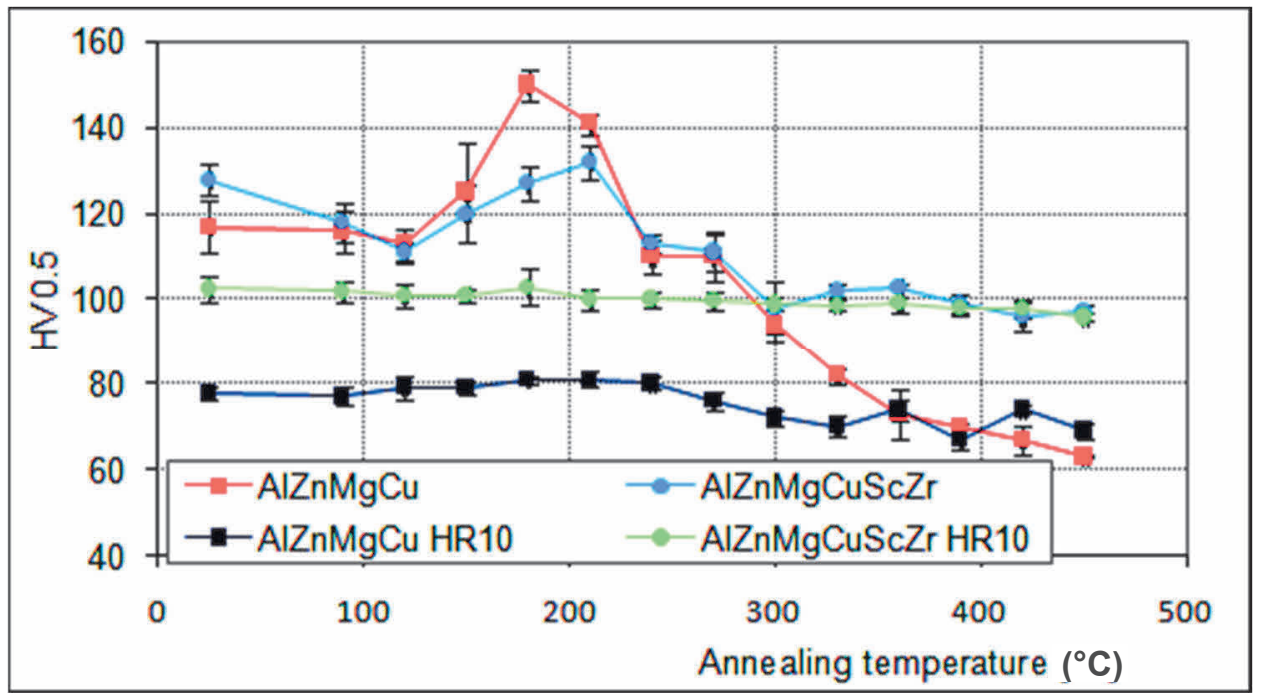

Figure 4 Isochronal annealing curves of microhardness HC0.5 changes measured at RT of the MC and HR10 AlZnMgCu(ScZr) alloys

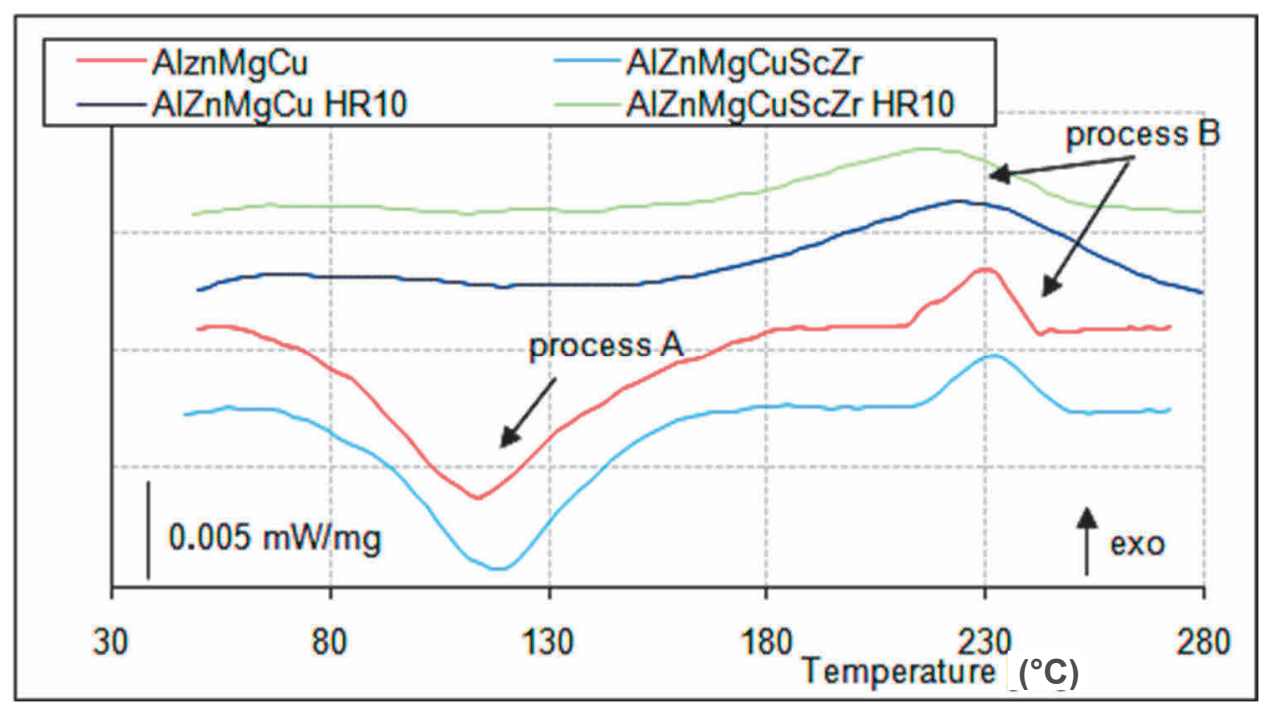

Figure 5 DSC curves at linear heating rate of $5 \mathrm{~K} / \mathrm{min}$ of the mould cast and HR10 AIZnMgCu(ScZr) alloys

The response of microhardness HV0.5 to isochronal step-by-step annealing of the AlZnMgCu(ScZr) HR10 alloys is shown in Figure 4. Higher initial values in the AlZnMgCuScZr HR10 alloy (HV0.5 $\approx 100)$ than in AIZnMgCu HR10 (HV0.5 80) are probably caused by presence of Sc,Zr-containing particles and/or by higher content of addition in the AlZnMgCuScZr alloy. Hot rolling has significant influence on microhardness values during isochronal annealing up to $450{ }^{\circ} \mathrm{C}$. There were observed no changes of microhardness values (in accuracy of measurement) from RT up to $450{ }^{\circ} \mathrm{C}$ in HR10 alloys. In the mould cast AlZnMgCuScZr alloy the hardening effect observed after annealing up to $360^{\circ} \mathrm{C}$ is caused by the precipitation of secondary $\mathrm{Al}(\mathrm{Sc}, \mathrm{Zr}$ ) particles [17]. We assume that these secondary particles and/or some particles of Al-Zn-Mg-Cu system 
precipitated during isothermal annealing at $300^{\circ} \mathrm{C} / 60 \mathrm{~min}$ and hot rolling in the alloys studies. The unchanging microhardness values from RT up to $450^{\circ} \mathrm{C}$ in $\mathrm{HR} 10$ alloys are probably due to the presence of these particles. However, further deeply microstructure research (using transmission electron microscopy) is needed to verify these assumptions.

Figure 5 shows DSC curves of the $\mathrm{AlZnMgCu}(\mathrm{ScZr}) \mathrm{HR} 10$ alloys at heating rate of $5 \mathrm{~K} / \mathrm{min}$ up to $270{ }^{\circ} \mathrm{C}$. Endothermic process A observed in the mould cast alloys [17] was not observed after hot rolling. This process is connected with the dissolution of the GP zones and/or clusters [17]. Dissolution of the GP zones and/or clusters was probably done during annealing at $300^{\circ} \mathrm{C} / 60 \mathrm{~min}$ and subsequent hot rolling. In the DSC curves of HR10 alloys only the exothermic process (process $\mathrm{B}$ ) was observed. The maximum of this process was at $\sim 218{ }^{\circ} \mathrm{C}$ in AlZnMgCuScZr HR10 and at $\sim 225{ }^{\circ} \mathrm{C}$ in the AlZnMgCu HR10 at heating rate of $5 \mathrm{~K} / \mathrm{min}$. The activation energy of the process $B$ was calculated using Kissinger method as $\sim 150 \mathrm{~kJ} / \mathrm{mol}$. Due to the temperature interval of the process $B$, maxima values and value of activation energy we assume, that process $B$ in the HR10 alloys is caused by precipitation the same particles (particles of Al-Zn-Mg-Cu system [17]) as in mould cast alloys. For verifying the assumption the further research is needed.

\section{CONCLUSIONS}

Results of the characterization of the hot rolled alloys can be summarizes in the following points:

a) Using EBSD was determined grain size as 1000 $\mu \mathrm{m}$ in the AlZnMgCu HR10 and as $\sim 20 \mu \mathrm{m}$ in the AlZnMgCuScZr HR10 alloy.

b) The eutectic phase was observed at (sub)grain boundary in the MC and HR10 alloys.

c) Primary multilayer $\mathrm{Al}_{3}(\mathrm{Sc}, \mathrm{Zr})$ particles were observed in the $\mathrm{AlZnMgCuScZr} \mathrm{MC}$ and $\mathrm{HR} 10$ alloy. Isochronal annealing up to $450^{\circ} \mathrm{C}$ has no influence on these particles.

d) There were observed no changes in microhardness values of the HR10 alloys from RT up to $450{ }^{\circ} \mathrm{C}$. Higher microhardness values were observed in the AlZnMgCuScZr HR10 alloy probably due to presence of $\mathrm{Sc}$ and $\mathrm{Zr}$ particles and/or higher content of addition in this alloy.

e) One exothermic process with maximum at $\sim 218{ }^{\circ} \mathrm{C}$ in the AlZnMgCuScZr HR10 and $\sim 225{ }^{\circ} \mathrm{C}$ in the AlZnMgCu HR10 alloy at heating rate of $5 \mathrm{~K} / \mathrm{min}$ was observed. This process is probably caused by precipitation of particles of Al-Zn-Mg-Cu system.

\section{ACKNOWLEDGEMENTS}

This work was supported by The Czech Science Foundation (GACR, project no. 17-17139S). VK acknowledges support by the project SVV-2017-260449 (Specific Academic Research Projects) and support by the Charles University, project GA UK No. 614119.

\section{REFERENCES}

[1] TOROPOVA, L. S., ESKIN, D. G., KHARAKTEROVA, M. L. and DOBATKINA, T. V. Advanced Aluminum Alloys Containing Scandium - Structure and Properties. Amsterdam: Gordon and Breach Science Publisher, 1998. ISBN 90-5699-089-6.

[2] DURSUN, T. and SOUTIS, C. Recent developments in advanced aircraft aluminium alloys. Materials and Design. 2014., vol. 56, pp. 862-871. DOI: 10.1016/j.matdes.2013.12.002

[3] VAKHROMOV, R.O., ANTIPOV, V.V. and TKACHENKO, E.A. Research and development of high-strength of AlZnMgCu alloys. In 13th International Conference on Aluminum Alloys. 2012. pp. 1514-1520. DOI:

10.1002/9781118495292.ch228 
[4] ROMETSCH, P. A., ZHANG, Y. and KNIGHT, S. Heat treatment of 7xxx series aluminium alloys - Some recent developments. Trans. Nonferrous Met. Soc. China. 2014. vol. 24, pp. 2003-2017. DOI: 10.1016/S10036326(14)63306-9

[5] ZHANG, M., LIU, T., HE, CH., DING, J., LIU, E., SHI, CH., LI, J. and ZHAO, N. Evolution of microstructure and properties of Al-Zn-Mg-Cu-Sc-Zr alloy during aging treatment. Journal of Alloys and Compounds. 2016. vol. 658, pp. 946-951. DOI: 10.1016/j.jallcom.2015.10.296

[6] YANG, X.B., CHEN, J.H., LIU, J.Z., QIN, F., XIE, J. and WU, C.L. A high-strength AIZnMg alloy hardened by the T-phase precipitates. Journal of Alloy and Compounds. 2014. vol. 610, pp. 69-73, DOI:

10.1016/j.jallcom.2014.04.185

[7] FENG, C.H., SHOU, W., LIU, H., YI, D. and FENG, Y. Microstructure and mechanical properties of high strength Al-Zn-Mg-Cu alloys used for oil drill pipes. Transactions of Nonferrous Metals Society of China. 2015. vol. 25, pp. 3515-3522, DOI: 10.1016/S1003-6326(15)63994-2

[8] YANG, W., JI, S., WANG, M. and LI, Z. Precipitation behaviour of Al-Zn-Mg-Cu alloy and diffraction analysis from $\eta^{\prime}$ precipitates in four variants. Journal of Alloys and Compounds. 2014. vol. 610, pp. 623-629. DOI: 10.1016/j.jallcom.2014.05.061

[9] GANG, S. and CEREZO, A. Early-stage precipitation in Al-Zn-Mg-Cu alloy (7050). Acta Materialia. 2004. vol. 52, no. 15, pp. 4503-4516. DOI: 10.1016/j.actamat.2004.06.025

[10] SHI, Y., PAN, Q., LI, M., HUANG, X. and LI, B. Effect of Sc and Zr additions on corrosion behaviour of Al-Zn-MgCu alloys. Journal of Alloys and Compounds. 2014. vol. 612, pp. 42-50. DOI: 10.1016/j.jallcom.2014.05.128

[11] HYDE, K.B., NORMAN, A.F. and PRANGNELL, P.B. The effect of cooling rate on the morphology of primary Al3Sc intermetallic particles in Al-Sc alloys. Acta Materialia. 2001. vol 49, pp. 1327-1337, DOI: 10.1016/S13596454(01)00050-7

[12] WANG, F., ESKIN, D., CONNOLEY, T. and MI, J. Influence of ultrasonic treatment on formation of primary AI3Zr in Al-0.4Zr alloy. Transactions of Nonferrous Metals Society of China. 2017. vol. 27, pp. 977-985, DOI: 10.1016/S1003-6326(17)60115-8.

[13] ZHOU, S., ZHANG, Z., LI, M., PAN, D., SU, H., DU, X., LI, P. and WU, Y. Effect of Sc on microstructure and mechanical properties of as-cast Al-Mg alloys. Materials and Design. 2016. vol. 74, pp. 44-48, DOI: 10.1016/j.matdes.2015.10.132.

[14] ZHOU, S., ZHANG, Z., LI, M., PAN, D., SU, H., DU, X., LI, P. and WU, Y. Correlative characterization of primary particles formed in as-cast Al-Mg-Alloy containing a high level of Sc. Materials Characterization. 2016. vol. 118C, pp. 85-91, DOI:10.1016/j.matchar.2016.05.011.

[15] VLACH, M., ČíZEK, J., SMOLA, B., STULÍKOVÁ, I., HRUŠKA, P., KODETOVÁ, V., DANIŠ, S., TANPRAYOON, D. and NEUBERT, V. Influence of dislocations on precipitation processes in hot-extruded Al-Mn-Sc-Zr alloy. International Journal of Materials Research. 2018. vol. 109, No 7, pp. 583-592. DOI: 10.3139/146.111654

[16] VLACH, M., KODETOVÁ, V., SMOLA, B., ČíZEK, J., KEKULE, T., CIESLAR, M., KUDRNOVÁ, H., BAJTOŠOVÁ, L., LEIBNER, M. and PROCHÁZKA, I. Characterization of phase development in commercial Al-Zn-Mg(-Mn,Fe) alloy with and without Sc,Zr-addition. Kovové materiály-Metallic Materials. 2018. vol. 56, pp. 367 - 377 . DOI: 10.4149/km-2018-6-367

[17] KODETOVÁ, V., VLACH, M., KUDRNOVÁ, H., MÁLEK, J., CIESLAR, M., BAJTOŠOVÁ L., HARCUBA, P., LUKÁČ, F. and LEIBNER, M. Phase transformations in commercial cold-rolled Al-Zn-Mg-Cu alloys with Sc and $\mathrm{Zr}$ addition. Journal of Thermal Analysis and Calorimetry. Under review. 